\title{
La escala urbana: evolución del pensamiento disciplinar para un relato identitario del territorio y del deseo
}

\author{
Sofía Letelier Parga
}

Filiación: Dra. Arqta. Sofía Letelier P., Prof. Asociada, Departamento de Diseño Arquitectónico, F.A.U. de la Universidad de Chile.

E mail: sletelie@uchile.cl

\section{Resumen}

A partir de comprobar primero que la escala es producción del deseo y que pensarla significativamente siempre ha requerido de un contexto el que debe poseer claras características, se muestra que la complejidad del pensamiento escalar del arquitecto se alcanzó a la par de la evolución conceptual teorizante que complejizó la propia disciplina. La influencia del territorio como contexto formador de nociones para la producción de una escala, proceso que se manifestaría recursivamente en recursos de percepción, concepción y dominio del espacio, es ilustrado aquí a través de las tipologías de agrupamiento urbano que imprimen diversos modos de medida perceptual, o bien que evitan su lectura dimensional intencionalmente, revisándose, finalmente, el rol que en ello han podido jugar en paralelo las ideologías.

Palabras clave: ESCALA URBANA; PENSAMIENTO ESCALAR; PENSAMIENTO ARQUITECTURAL; PENSAMIENTO RECURSIVO; ESCALA Y TERRITORIO.

\section{I ntroducción ${ }^{[1]}$}

A diferencia de algunos fenómenos físicos en los que el hombre no interviene cuando le impactan (como ante el sorpresivo rayo que le sobrecoge durante una tormenta), otros como la escala arquitectónica y urbana, son fenómenos que, cuando le impactan, al mismo tiempo le involucran ya que dependen de él. Porque siendo lo que llamamos 'escala' una cualidad secundaria de los objetos construidos en el sentido aristotélico, porque la misma escala no es distintiva ni necesaria de 'todos' los objetos arquitectónicos , necesita de la 'consciencia' para manifestársenos en un cierto estado, para inducirnos a caracterizarla y hasta a darle un nombre: las cosas no dejan de ser 'casa' o 'calle' cualquiera sea la escala; pero, como resultado de múltiples vectores subconscientes, requieren de 'consciencia' y de intencionalidad para ser caracterizadas ya sea en su magnificencia o humildad. Y tal grado de 'consciencia' es necesario tanto en instancia de 'lectura' del lugar o durante la concepción proyectual.

Pero, dado que las relaciones y referencias que establece un individuo con memoria y circunstancia siempre tienen en parte una base cultural y social que se ancla en el imaginario colectivo del 'espacio habituado', tanto los recursos escalares como los efectos dimensionales que se buscan conscientemente con ellos, se imbrican en el tejido de un relato subconsciente de sentido que es común. Por eso resulta importante dilucidar el proceso de la formación de esos contenidos colectivos de sentido que terminan por imprimir rasgos recurrentes que afloran a la 'consciencia', ya sea en rasgos formales, de dimensión, o de organización que finalmente inducen determinada preferencia y búsqueda de percepción de escala.

Estamos suponiendo que es el modo en que los contenidos arquitectónicos/urbanos se forman y emergen, convergiendo a un sentido que hace sentido a la sociedad; que se han ido acrisolando

[1] N. de R. El presente artículo corresponde a un extracto de la Tesis Doctoral de la autora: Lectura e ideación de la escala y "escalaje" en Arquitectura: inteligencia visual que adquiere identidad en la Geografía, Director de Tesis Dr. Arqto. Guillemo Cabeza Arnaiz; Co-Director Dr. Ing. Julio Pozueta Echavarry, ETSA, Universidad Politécnica de Madrid, 2007,507 páginas ilustradas; Sobresaliente Cum Laude. 
colectivamente, al aflorar aquí y allá, y de vez en cuando, de manera análoga a los ritournelles (o estribillos) sociales de origen anónimo que, según $F$. Guattari ${ }^{1}$ se conservan con matices en cualquier expresión verbal y no verbal de carácter local. Para el caso de la arquitectura, hemos detectado y descrito ya el surgimiento de 'estribillos' como rasgos del hacer colectivo inopinado y que son basamento de la operación de lenguajes no verbales más complejos ${ }^{2}$. Rasgos que serían recursivos también en arquitectura porque de acuerdo a $\mathrm{M}$. Foscari ${ }^{3}$ se aprecian sólo y finalmente en el propio sentido que ellos mismos alcanzan y condicionan en el relato, como hecho efectuado.

Tales ideas de recursividad de los contenidos sociales, al complementarlas con los recientes hallazgos de la ontogeografía de J. Malpas (2004) ${ }^{4}$ quien postula la trascendencia y recursividad de la nociones nacidas de la comprensión del territorio , nos permiten dejar en evidencia cómo el relato o narrativa comprensiva del espacio como hecho social tiene un rol desde su concepción, percepción y producción como lugar; y que sus sucesivas operaciones de 'escalaje' resultan ser el más activo agenciamiento narrativo, aunque se efectúe subconsciente a nivel social.

En nuestra investigación hemos podido comprobar que la 'arquitecturidad' de los relatos y de todo acto manifestativo (disposiciones particulares y dimensionamiento de los elementos de manifestación social), así como también la narratividad que está en potencia en todo lo físico para ser manipulado hasta llegar a ser descripción de deseos, de comportamientos y de eventos, según el discurso de J. Seguí ${ }^{5}$, pueden concurrir legítimamente al estudio de la escala, si ésta una particular qualia de lo arquitectónico/urbano, su accidente dimensional, se mira como un relato colectivo de significación del espacio.

Pero la disciplina de la arquitectura y del urbanismo ha debido recorrer un largo camino para aceptar y conceptualizar tanto el concepto mismo de escala como su proceso social; para disponer de herramientas explicativas de los fenómenos escalares 'de hecho', operados empíricamente de modo magistral; y para orientar predictivamente la producción dimensional con alguna certeza de efectividad perceptual.

\section{1.- La Escala como producción del deseo existe, aún en ausencia de contexto.}

Para probar que en la formación de contenidos y de códigos colectivos como los que se expresarían en la escala arquitectónica /urbana influye el 'entorno geográfico habituado', debimos ponernos en el caso extremo de que éste no exista.

El análisis de algunos concursos de arquitectura dejó en evidencia que cuando la competencia se abre a temas raros y a proposiciones muy libres sin un contexto, las ideas se vuelven en extremo introvertidas o bien mono referenciadas, generalmente a módulos tecnológicos o al propio cuerpo

únicos patrones que restan conocidos, y también, que en estos casos tales referentes curiosamente son empleados en su dimensión más lúdica e improbable, de modo que se dificulta utilizarlos como referencias para inferir la dimensión del total, porque el contexto es necesario. Y, cuando el concurso se trata de arquitectura para una situación urbana singularísima y de alta carga simbólica, pero donde lo geográfico resulta indiferente por ser un territorio ilimitado y plano, por ejemplo , la escala de lo propuesto inevitablemente se agiganta, desplegándose en un espacio de referencia que ya no intenta contener al hombre físico real sino a una idealización de un determinado y supuesto 'estado de la humanidad' que 'merece' esa situación y envergadura.

Algunos ejemplos de concursos 'sin contexto' o con 'contexto indiferente' resultan indicativos: en su número temático 'Scale' - de la serie 'Young Architects'-, dedicado a los ganadores del “Architectural League's Annual Competition" de $1999^{6}$, la teórica Nina Rappaport consigna en la introducción que la escala que se desprende de los proyectos de "estos jóvenes arquitectos de Nueva York ganadores de la sección con tema libre, a pesar de su gran diversidad, mantienen aún 
como patrón común la referencia al cuerpo humano". Sin embargo, desde nuestro análisis se desprende que esa referencia al cuerpo humano no es de tipo dimensional o en el sentido tradicional del término 'escala humana': una revisión detenida de las imágenes concursantes de los numerosos proyectos todos desarrollados por medios digitales nos lleva a concluir que, más que la referencia al 'cuerpo humano', cuya sola mención nos direcciona a sus dimensiones físicas o a considerarlo en sus movimientos y alcances en un sentido ergonométrico, lo que abordan esos jóvenes inconscientemente es más bien lo que pudiéramos denominar 'la escala de los problemas actuales de lo humano', escala que es otra que la del cuerpo físico. Porque de las imágenes de los 20 proyectos sin contexto, se deduce el siguiente orden de problemas que preocupa a los jóvenes arquitectos:

- El alcance del recurso digital en sí. La potencialidad espacial del 'rendering' virtual;

- la existencia nomádica de la sociedad en el presente;

- el paisaje (entendido en el sentido indígena), con su inestabilidad y cambios cíclicos de luz;

- las nuevas sorprendentes dimensiones y formas que permiten los nuevos materiales y tecnologías;

- consideración de sombras, su mutabilidad y capacidad de transformación del soporte;

- la convivencia de polos significativos simultáneos, especialmente 'grande / pequeño';

- el problema del espacio público versus el valor de la individualidad;

- la hibridación de funciones e indeterminación de programas; lo indecidible funcional;

- las ilusiones; lo real versus lo irreal; lo equívoco de materiales con reflejos y transparencias;

- los efectos del cuerpo en movimiento; la apropiación espacial en el tiempo;

- la multifuncionalidad; estructuras transformables; el tamaño arquitectónico indeterminado;

- las nuevas y distintas funcionalidades que propone 'el concepto de género';

- objetos utilitarios cada vez más grandes (como el 'home theater') en espacios cada vez más pequeños;

- la 'intermediación', con efectos y sarcasmo hacia lo establecido;

- ruptura de códigos; 'nuevas formas, nuevos materiales', frente a preexistencias.

Tales temáticas y su formalización en los proyectos mismos evidentes en las imágenes, (Figs. 1 a 4) dan cuenta del espacio mental postmoderno del que estos jóvenes son exponentes; espacio caracterizado por la exploración de límites, la intuición de nuevos temas y la transgresión a las convenciones de la disciplina, pero que los jóvenes sorprendentemente resuelven en definitiva apelando a un mecanismo convencional: el contraste con lo próximo, en escala y proporciones. Porque, si bien es cierto que en ellos se aprecia una visión sarcástica y provocadora de lo establecido tanto en las temáticas que se auto impusieron como en las expresiones de agudos contrastes, equívocos espaciales, superficies indeterminadas, colisiones, fragmentaciones, etc., y en el uso innovador e inhabitual de la mayoría de nuestros recursos disciplinares, pudo verse que no sólo la escala subsiste como deseo, sino que se la utiliza como 'el' fundamental recurso de provocación. Se podría decir que mientras todo lo demás es puesto hoy en tela de juicio, la escala

esa relación significativa del tamaño de las cosas permanece como vector comunicativo. Y que, en ausencia de un territorio geográfico dado, aunque los autores tuvieron toda la libertad de situarse, eligen sin embargo eludir claves exteriores con excepción de la luz, privilegiando la interioridad. Ello da cuenta indirecta y por antítesis de la importancia del contexto para pensar claves de escala. 


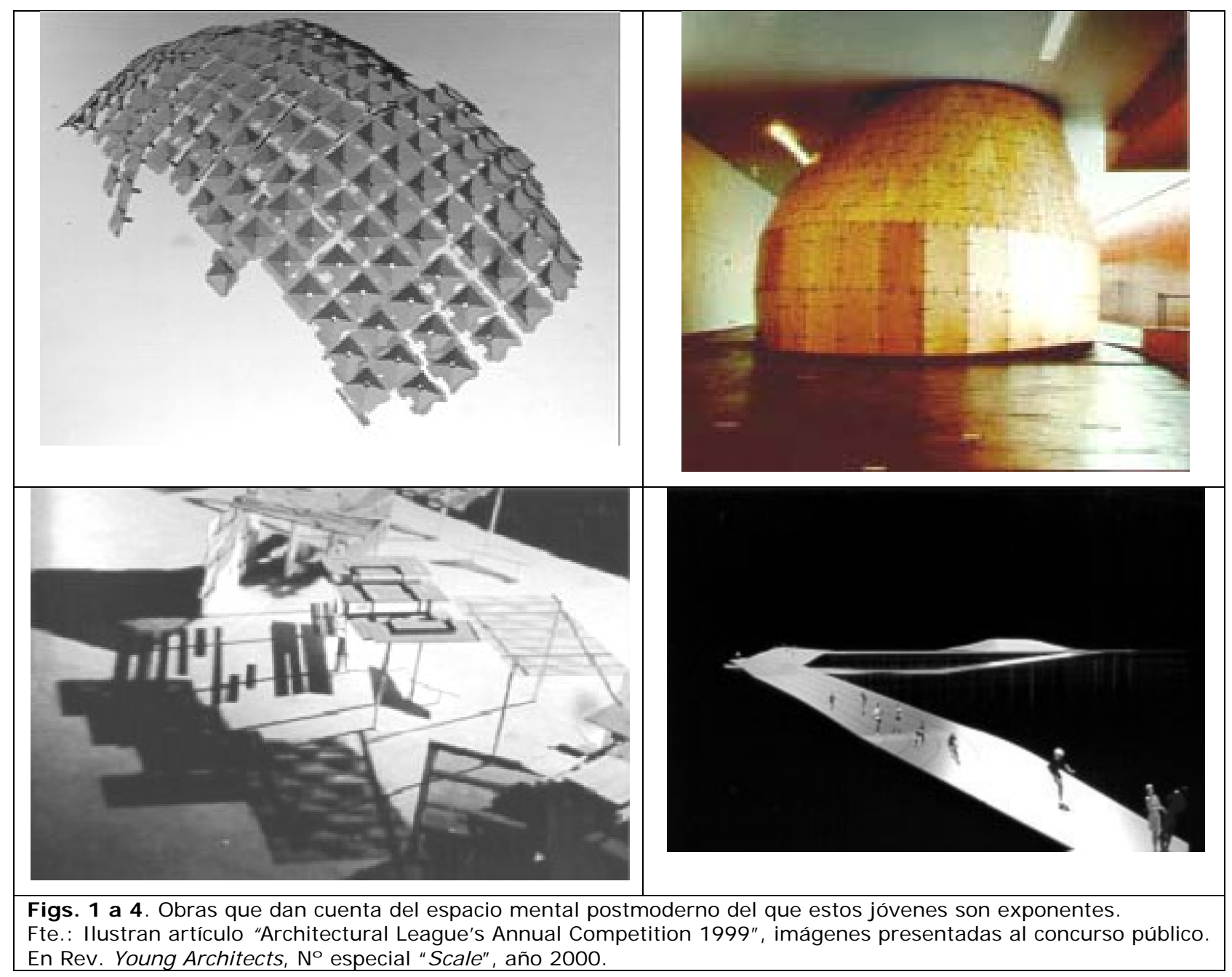

Y en los concursos en que participan arquitectos consagrados pasa algo igualmente notable respecto de la escala cuando el contexto es sordo o indiferente: parece exacerbarse la conciencia de que el estado presente de la tecnología en el mundo desarrollado permite soñar con la posibilidad de casi cualquier dimensión de obra, haciendo que se subvierta con facilidad aquella escala que en el pasado dictaba la certeza de la dimensión física posible, esa que era factible con los recursos tradicionales en un contexto determinado. E igual que en los proyectos de jóvenes, el hecho de la no presencia evidente del contexto geográfico no es trivial para arquitectos consagrados, cuando son convocados a resolver situaciones de excepcional singularidad.

La revista 'AV Proyectos' № 004-2004, publicó los proyectos postulantes del concurso para la remodelación del paño urbano de Les Halles en París con un amplio programa de servicios públicos. Concurrieron, entre otros, arquitectos o equipos de la talla de OMA/ Rem Koolhaas, (Fig 5), Jean Nouvel (Fig.6), además de MVRDV y otros, proyectos todos que asumiendo la alta carga simbólica del lugar ¡o el de su propia notoriedad! no buscan mimetizarse con el entorno urbano, 0 al menos no perturbar la escala circundante, respeto que antes se había propuesto en forma elocuente el conocido complejo del Forum a demoler, construido en 1979 (Fig. 7). 


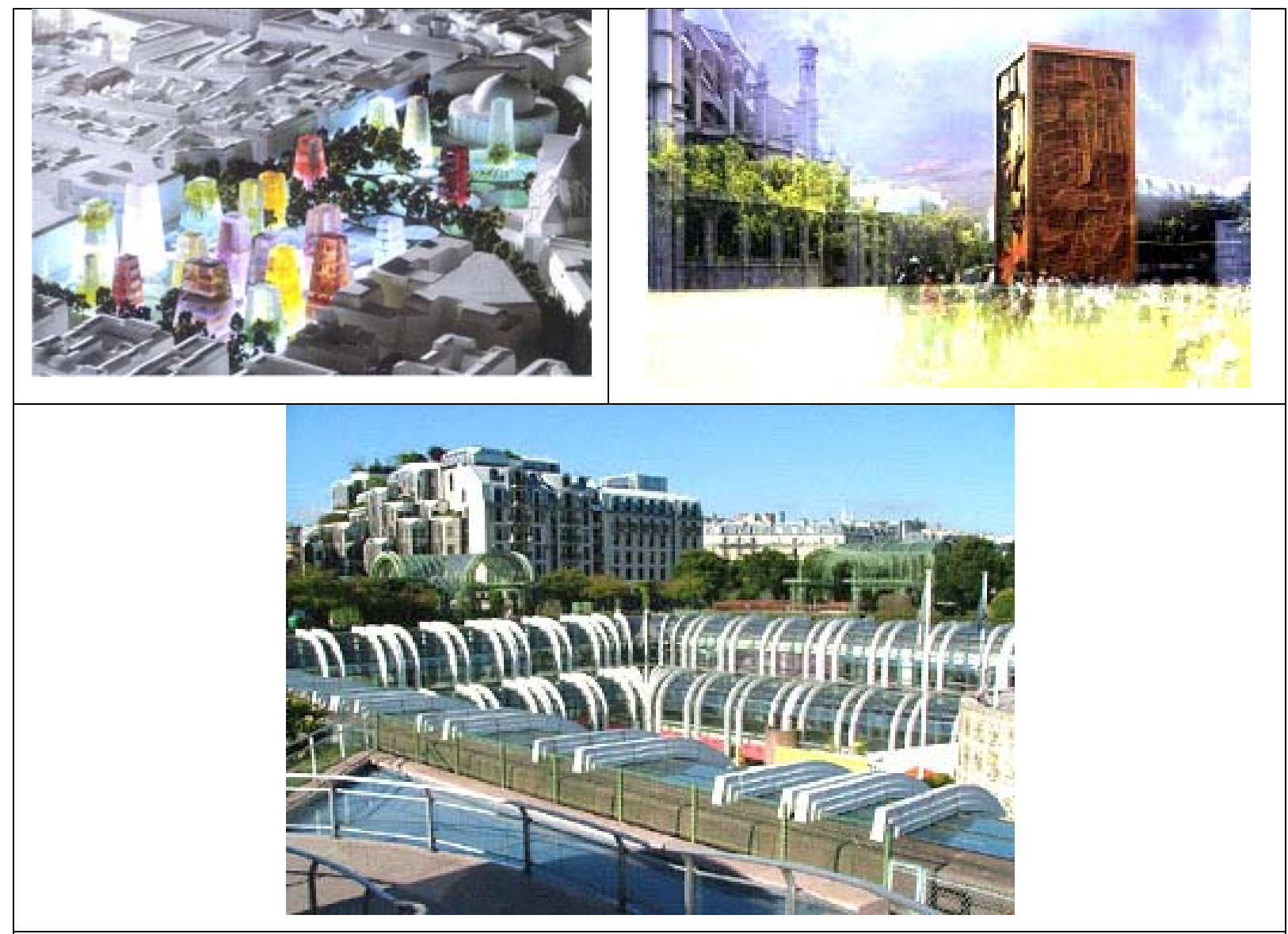

Fig.5, Rem Koolhaas; 6, Jean Nouvel, y 7, el antiguo Forum de Les Halles, con menos sentido simbólico, adopta una escala introvertida y adaptada al lugar.

Fte. Ilustran artículo sobre remodelación del paño urbano de "Les Halles" en París; imágenes presentadas al concurso público. En rev. 'AV Proyectos' № 004, año 2004.

Los arquitectos ahora saben que la introducción de un conflicto entre lo habitual y lo inhabitual como se advierte en todas estas nuevas proposiciones es un recurso fácil para atrapar la atención con seguridad, dado que al no pasar desapercibido establece con certeza el estado de consciencia necesario a la percepción general y, en particular, a la percepción escalar. En todos los casos este juego escalar, como instrumento de trasgresión a la vez que de condensación para segregar sobre seguro lo nuevo de lo antiguo, es evidente. En todos la escala de los nuevos edificios imponen una fuerza centrípeta y autista frente a la del entorno urbano y geográfico. Los autores parecen confiar en que el destino singular y simbólico puede redimir de la obligación de 'escalarse' frente al entorno, lo cual en cuanto al entorno geográfico será más fácil en territorios llanos (como Francia) y más difícil allí donde los hitos geográficos son rotundos e imposibles de competencia o de evitar, por su altura.

Puede inferirse entonces que, en ausencia de un contexto real los proyectos de los jóvenes o en ausencia de hitos geográficos notables en alturas que acoten el espacio los propuestos en el llano de París por los arquitectos consagrados , la escala de los edificios no es que no exista, sino que se hace aleatoria y autorreferente, siendo imposible encontrar una escala dialogante. De modo que por antítesis pudiera confirmarse, preliminarmente, la importancia del territorio en las decisiones escalares y en el manejo de códigos identitarios de escala. 


\section{2.- Maduración del concepto de escala: evolución del pensamiento disciplinar.}

Curiosamente, un término tan corriente hoy como la 'escala arquitectónica y urbana' en tanto categoría de juicio, pero también su identificación como legítimo fenómeno de manifestación de sentido del espacio , estuvo larvada y tácita en la disciplina hasta el siglo XIX, cuando Eugene Emmanuel Viollet-le-Duc precisó y definió en sus tratados 'Entretiens sur l'architecture' (1863) e 'Histoire d'une maison' (1870) el concepto de 'escala' para la arquitectura, a pesar de que venía perfilándose en la misma línea de evolución por donde venía transitando la disciplinación del pensamiento arquitectónico.

La escala, en el estado conceptual presente que como sabemos va mucho más allá del patrón o cartabón para la transferencia de dimensiones de una realidad a otra, ha llegado a entenderse como un juicio significativo que infiere un orden de magnitud tridimensional para ese objeto, en función de un conjunto de factores físicos, psíquicos y culturales que se han ido esclareciendo en la disciplina muy lentamente.

No obstante, la manifestación de determinado fenómeno escalar desde el hacer empírico mediante materiales físicos en el espacio y en un lugar, con el fin de inducir un cierto juicio sea de modo subconsciente o como producción intencionada, parece ser y haber sido una vocación consustancial al hacer arquitectónico: su trasfondo siempre da cuenta de la conceptualización subyacente con que se instrumentaliza la escala en el momento, según el estado del pensamiento arquitectónico.

Parece evidente que 'la escala' siguió el desarrollo mismo de esa cualidad que llamamos «arquitectura». Si bien no existía el término hasta hace menos de 200 años, ella permanecía tácita en la progresión intelectual de la cultura arquitectónica: había evolucionado desde un mero carácter expresivo logrado como acento en algunas dimensiones de las obras en el período arcaico , a la proporción, asunto más abstracto en tanto relación de dimensiones. Esta última, utilizada en forma icónica e instituida en órdenes prescriptivos por mucho tiempo, desarrolló un mecanismo de pensamiento para hacer identificable determinado carácter consensuado e independiente del tamaño, dejando con ello implícita la no preocupación por el efecto del entorno que, de este modo antitético icónico, se intentaban contrarrestar (si me identifico como manzana o como lápiz, no importa el tamaño que tenga ni el entorno en que esté).

En tanto, el efecto escalar apareció subrepticio junto a la proporción ideológica y localizada que introdujo el Renacimiento, al perseguir esa esencialidad de los edificios con pertinencia al lugar; lo que obligó a generar una herramienta como la perspectiva matemática para expresar el deseo de espacio y las distancias adecuadas. Con la perspectiva se puso la semilla de 'la escala', al instalar cánones más relativos y complejos que derivaron hacia la proporción expresiva y alegórica del Barroco, estilo que permitió, desde el siglo XVIII, la emergencia germinal de la 'escala' aunque tácita aún , siendo reconocida explícitamente como un fenómeno perceptivo específico que afecta a la significación recién en el siglo XIX. Para llegar en el siglo XX a la escala pragmática del Racionalismo en arquitectura, hasta expandirse en diversas acepciones que nos dejan intuir ese concepto abarcante y multifactorial de la escala, total y totalizador, que hoy sentimos que caracteriza lo presente en su referente contextual.

No obstante, esta complejidad actual, en su sentido más limitado y común de mero instrumento y de procedimiento de reducción o de ampliación en gráficos u objetos que sirven de interfase para transferir ideas a la realidad con el fin de llevarlas a un estado aprehensible, la escala había funcionado inalterada desde el auge de Mesopotamia. La constancia más antigua del procedimiento homotético es la estatua de Gudea 'el Arquitecto', rey de Lagash hacia el año 2100 A.C., conservada en el Museo del Louvre y que sostiene un plano de una ciudad en su regazo, anterior al conocido plano de Nipur. (Fig 8). 


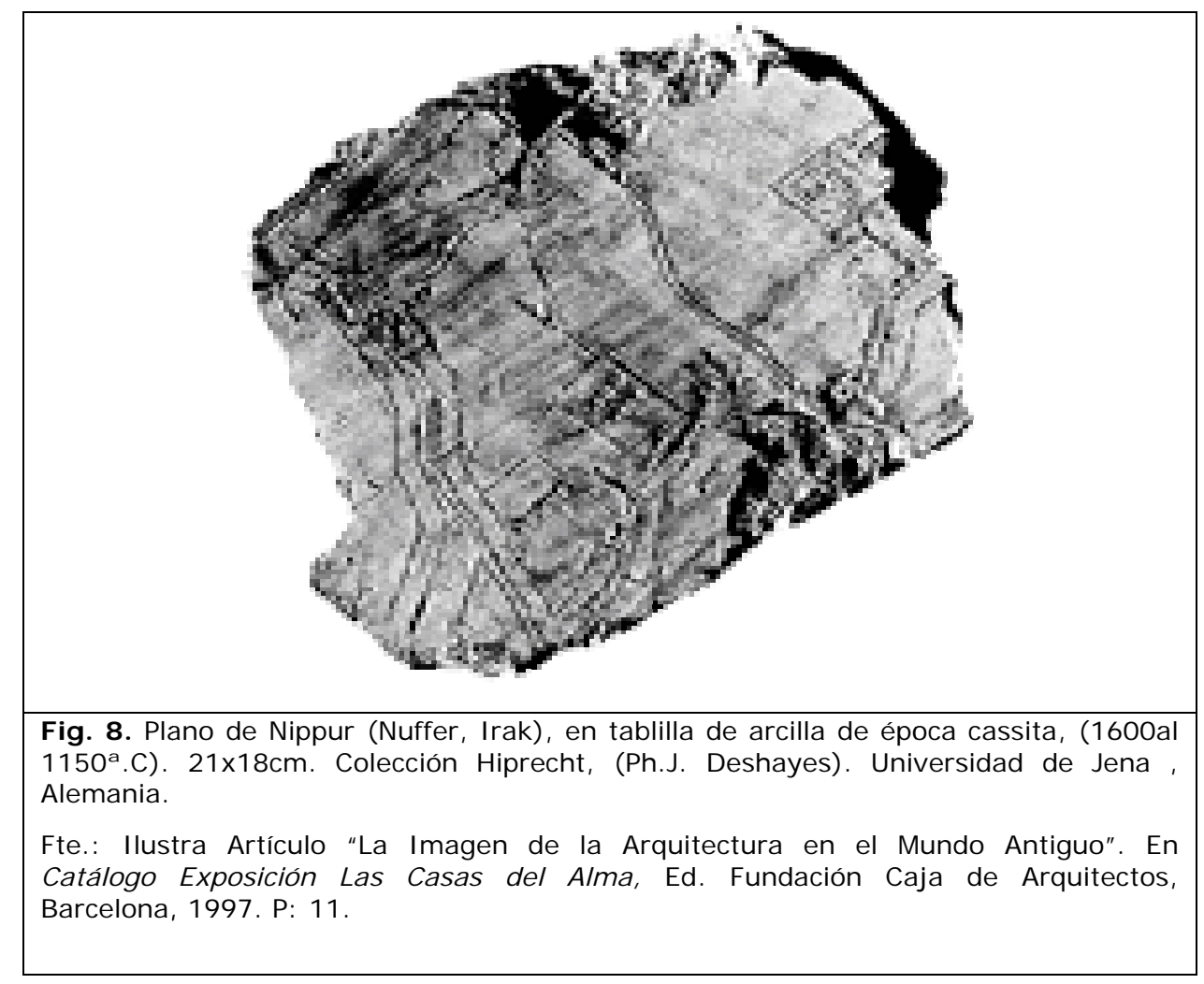

Y otra clase de reducción arquitectónica no ya homotética porque no hacía uso de referentes ni patrones exactos, sino sólo de imágenes compartidas socialmente dejó también preciosas huellas como recurso ritual de operación con sueños colectivos, es la práctica egipcia que se ha denominado 'casas del alma', singular conjunto de miniaturas de edificios imaginarios, íconos o juguetes cuya utilidad se especula ligada al deseo. Si bien se les suponen fines de conjuro, de representación de posesiones o de objetos esperados verdaderos sustitutos y no maquetas, la reducción era también allí manifestación imaginística del deseo, del mismo modo que hoy las maquetas anticipan un proyecto. Objeto que, con el tiempo, fue transformándose en campo e instrumento de decisiones, "la maqueta es el juguete del artista dirá J. Ramoneda , porque jugando con ellas, el creador siente el placer de los dioses: ordena el mundo según su criterio y capricho" 7. Es hasta el Renacimiento que los planos y maquetas técnicas mantuvieron ese componente mágico o sagrado; porque levantar pirámides o catedrales y hasta ciudades eran operaciones casi milagrosas que se explicaban por intervención de fuerzas sobrenaturales, debiendo ensayarse en símiles antes de ofrecerse a la advocación protectora.

\section{1.- Bases evolutivas para el concepto de escala en el Urbanismo.}

Hasta el período grecolatino los conjuntos arquitectónicos del tipo villas o palacios crecen por agregación de edificios que son entidades autónomas y completas totalidades en sí 'pregnantes' diríamos hoy, debido a la intencionada segregación autorreferente que les imponen internamente su simetría y los cánones proporcionales: sus componentes pueden ser replicados en diferentes tamaños, siempre reconocibles, porque en ellos el total y cada parte respondía a una idea, cada parte era una estructura formalizada en términos estructuralistas susceptibles de identificarse, independientemente de su magnitud (Fig. 9). 


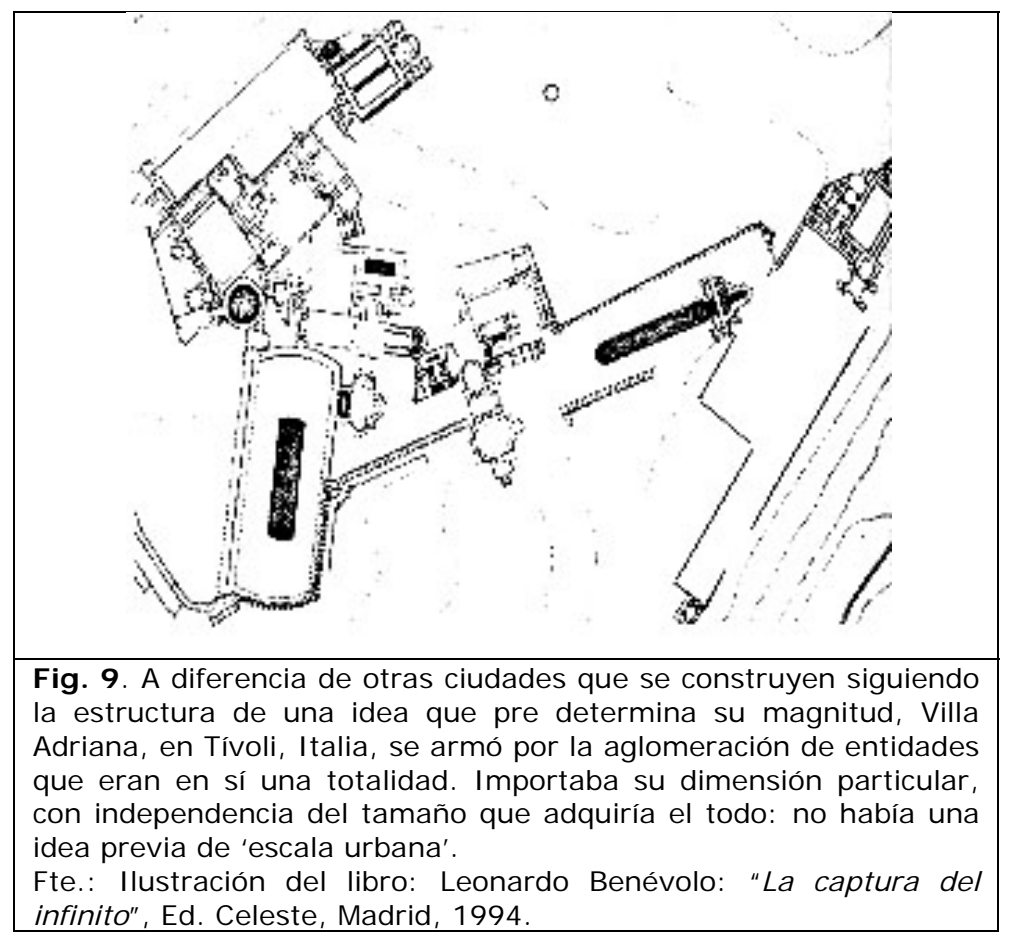

La agregación del conjunto, en cambio, no obedecía a 'una idea' preconcebida según se ve en Villa Adriana (Fig. 10), como lo hacían los elementos o edificios singulares y el trazado global de las ciudades. Según Pedro Azara ${ }^{8}$, autores como Vitruvio y Plutarco llamaban 'ideas' a los dibujos de arquitectura que contenían la distribución en planta y alzado de las partes de un edificio. Pese a que el proyecto es un hecho sensible y no sólo un inteligible, el uso de ese término sería acertado porque, en efecto, originariamente eídos significaba "forma" o carácter propio que se exterioriza: cada edificio era un tipo y a la vez una idea completa.

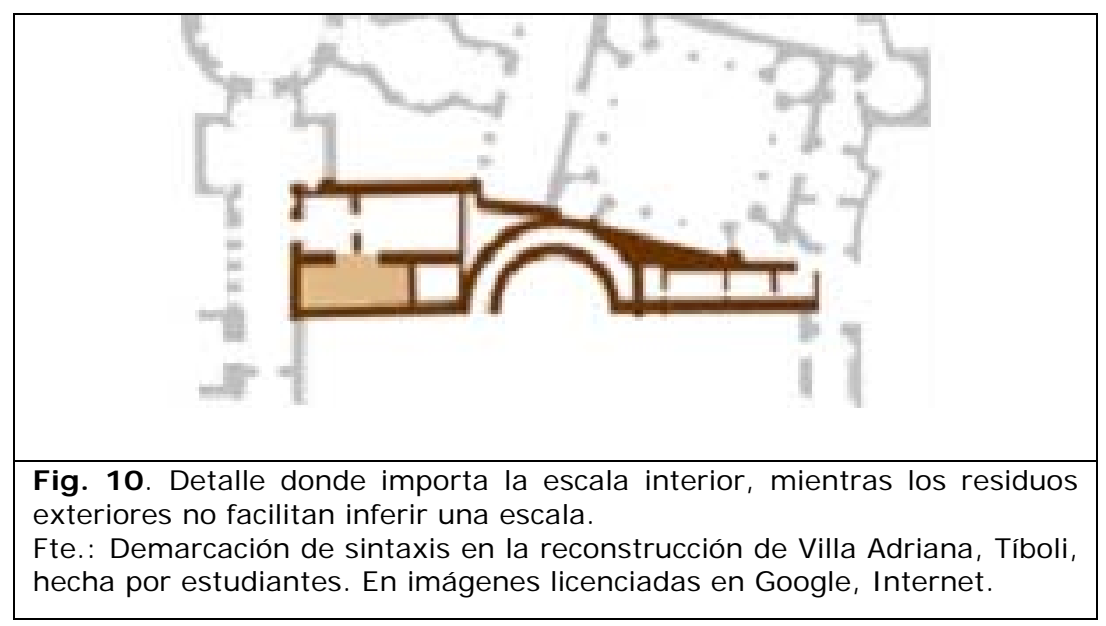

Pero las ciudades del mundo antiguo no respondían a una idea acabada, aunque se documentan claras maneras de decisión dimensional y posicional que establecen relación entre las partes y de 
éstas con el territorio, y hasta de dominio equitativo, como el damero hipodámico , si bien de un modo distinto al que lo hará la conciencia de escala urbana total con posterioridad: las ciudades “..se orientaban en una estructura según el curso de los astros... la fundación de las ciudades era precedida por complejos rituales... Hacer arquitectura [en el período antiguo] implicaba reordenar mágicamente el mundo, imitando el primigenio obrar de los dioses", señala Azara. Sólo con la emergencia posterior del recurso del escalamiento empírico, ya no se tributará a la Naturaleza cósmica, sino a la más próxima y palpable, pudiéndose imitarla o competirle. El dominio de unidades iguales permite ir abarcando el territorio por adición, adaptándose a su configuración con una medida que permite dimensionarlo. Fue una conquista de la Antigüedad que se re descubrió en el Renacimiento (Fig. 11), exportándose a América: ritmadas a la medida de 'cuadras', en el sistema aditivo pero no expansivo; mientras los esquemas radiales instan a percibir expansión que se aleja desde un punto, los sistemas aditivos, como el damero, pueden crecer. Pero, a diferencia de las ciudades radiales, no dan la sensación de un mismo ente que se expande, dado que es un sistema sin origen, o bien éste es arbitrario.

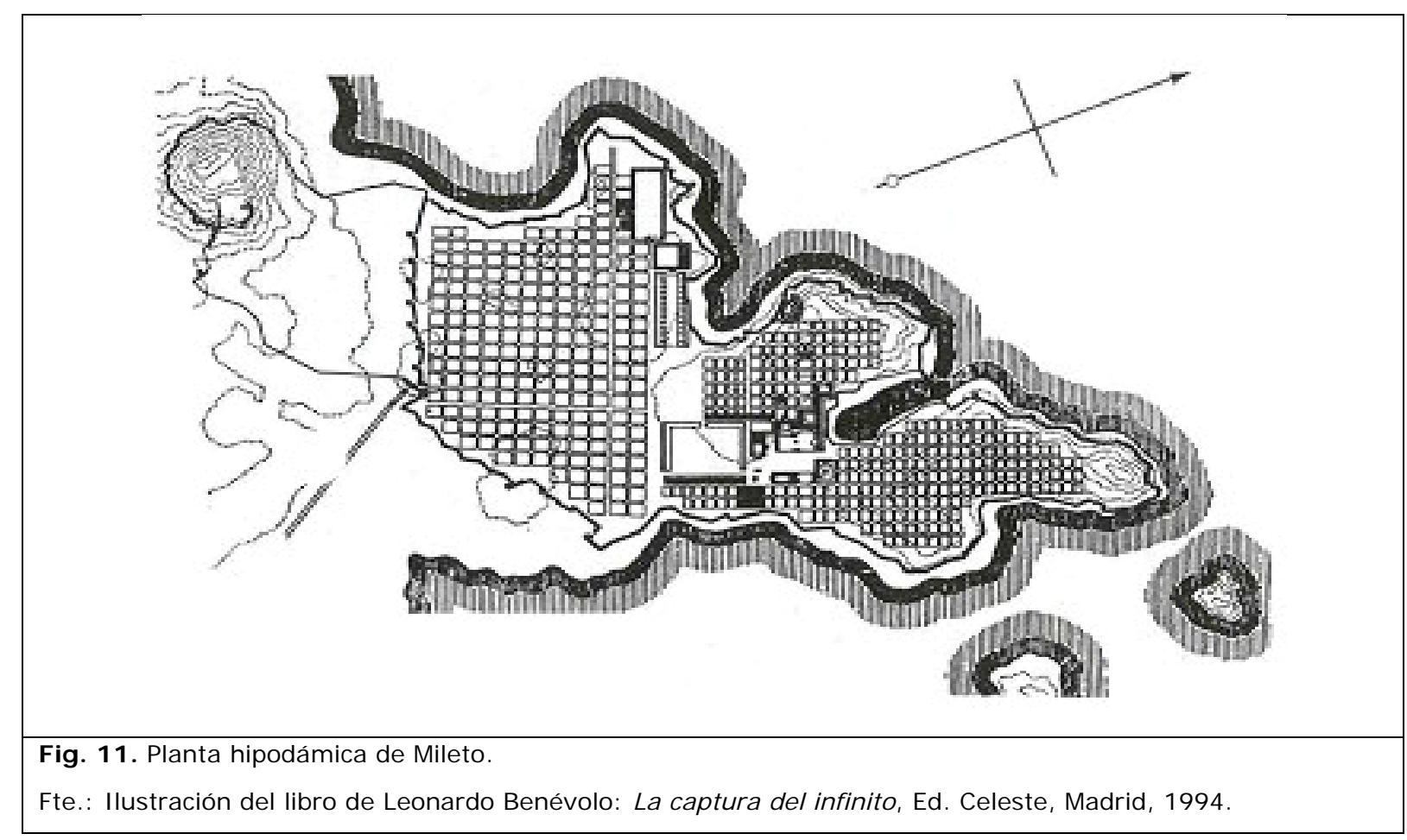

Durante el período Gótico se postergó esta manera de dimensionar el espacio de los hombres en procura de realzar otros valores. Las naciones que habían invadido Europa trajeron distintas y nuevas aproximaciones a la dimensión como la relativa al uso práctico y a la expresión , haciéndola más funcional y desinhibida hacia aquellos cánones que no les eran propios; e instalan dimensiones pragmáticas o simbólico analógicas, alusivas a imágenes de su mundo boscoso de proveniencia, como observa Worringer ${ }^{9}$. Ello lleva a que una serie de elementos de la arquitectura, especialmente los más próximos al usuario, adquieran nuevas posiciones y dimensiones dentro del texto. Tales dimensiones prácticas resultaban tan rupturistas que, al ser analizadas posteriormente durante el siglo XIX por Viollet-le-Duc ${ }^{10}$, le llevan a consagrar la utilidad de la referencia al cuerpo medidas antropométricas de uso y de movimientos instalando el concepto de "escala humana" 
y, a continuación, el concepto más amplio de 'escala' ligado a otras referencias, del modo como la entendemos hoy.

Esta verdadera puesta en crisis de la proporción esencial que surge con la aparición en el siglo XI de las construcciones góticas particularmente crisis de la 'buena proporción', por entonces entelequia que se había hecho cada vez más abstracta, obedeció también en gran medida a la influencia del pensamiento escolástico que impusiera la filosofía de Tomás de Aquino, y que aportó según Panofsky ${ }^{11}$ nuevas formas de distinción y de articulación de las ideas. Porque, no obstante que el recurso piedra para construir había sido el mismo desde el principio de los tiempos hasta entonces, con el Gótico se revolucionan las formas diversificándose los elementos acorde la transmisión de esfuerzos y, llevadas al límite de su posibilidad, se alteran sus dimensiones. Los edificios se elevan con ligereza "a pesar de la piedra" en términos de Worringer, con una voluntad audaz antes desconocida. De modo que 'la proporción' de elementos y del todo, de la ciudad, espacios públicos y partes como se la había entendido en el mundo clásico atenido a las posibilidades constructivas dolménicas, ya no volverá a ser igual ni puede constituir más una razón fija. Por ello, cuando se retoman los estilos greco latinos durante el Renacimiento, la proporción ya no es un 'dado' convenido sino que constituye un tema de decisión. Si bien subsistían órdenes o prescripciones proporcionales, éstas no estaban sólo referidas a la propia coherencia del elemento tectónico sino también a buscar otras armonías en el entorno como recurso de relación; se pone profundamente en crisis el sistema de proporciones fijo cuando, con cada inserción arquitectónica, los renacentistas se obligaron a dialogar con el total del contexto construido y con el espacio circundante. Desde entonces se hizo fundamental preocuparse de una aún no explicitada escala, adecuando o sometiendo las proporciones de lo nuevo al entorno.

Ya en el tratado De Re Aedificatoria, de 1485, Gianni Battista Alberti declaraba que «en número, tamaño y localización, las partes de un edificio responden unas con otras, debiendo ser igualadas, balanceadas y puestas con gran cuidado» 12. En esta adaptación y relativización de las proporciones y otros aspectos que inciden en el concepto posterior de escala, Alberti resulta precursor. Un estudio detenido de las proporciones de las obras de Palladio puede acercarnos a este tipo de ensayos de pensamiento y descubrimientos proto escalares renacentistas que aportan una magistral alteración de proporciones y reformulaciones semáticas, adaptando elementos, vanos y alturas a cada situación.

Leonardo Benévolo, al abordar la incidencia de la perspectiva en tal momento, atribuye carácter de 'revolución conceptual' al cambio acaecido en el siglo XVI e implícitamente, describe, a nuestro juicio, el surgimiento de las bases del concepto de escala, aunque no la menciona ${ }^{13}$. Sostiene que con el descubrimiento de la perspectiva, en el siglo XVII en occidente, cuando "se intenta representar físicamente el infinito en el campo de las grandes dimensiones y aumentar la percepción perspectiva" con recursos específicos, es que verdaderamente se acepta la relatividad de lo percibido; y ello se traduce no sólo en la pintura sino en el acondicionamiento arquitectónico de los espacios físicos para dominarlos en la máxima extensión horizontal. "El desafío enfrentado [por la arquitectura] entre el siglo XVII y XVIII es el desafío de la realidad: ampliar concretamente, de un modo visualmente perceptible, los límites posibles de la perspectiva", dice Benévolo ${ }^{14}$. Así, la posibilidad de registrar la extensión visual infinita que ofreció el nuevo artificio gráfico de la fuga no afectaría sólo a la proyección imaginaria sino que al paso de la proyección a la ejecución: en consecuencia, se buscó en el período dar realidad a la concepción de nuevos alcances, como por ejemplo, poder precisar objetivamente la extensión del concepto de "un kilómetro" definido por entonces intentando en las obras, especialmente de jardines, que ello fuese percibido. Se aprovecha así recién en plenitud el hecho de que Aristóteles en la Antigüedad había definido el "lugar", no como un espacio vacío donde están los cuerpos, sino como un espacio definido por ellos y dependiente de ellos.

Es en el siglo XVIII después que los avances en ciencias demandan mayor exigencia de explicaciones, cuando en el pensamiento arquitectónico surgen los primeros tratados teóricos e ilustrados con Laugier y Blondel (1753), y se divulgan los grabados de Antonio Piranesi (1748-62), 
es cuando queda a disposición un repertorio vasto de formas de toda la historia arquitectónica que amplían los recursos y, con ello, la posibilidad de ensayar juegos perceptivos. Ante esta abundancia de modelos, la confianza en las reglas tradicionales, cánones y normas de proporción, pierde su carácter constrictivo, y el acopio de formas se convierte en un repertorio disponible para el juego escalar. El código formal y proporcional ya no es fijo y se entiende ahora "según su circunstancia de uso", acota Benévolo. Con ello, parecen estar maduras las bases para el concepto de escala aún innominado en el occidente europeo. Porque en este escenario, más flexible, variado y sistémico que se abre a la arquitectura del siglo XVIII, si bien las reglas de la perspectiva gráfica y del deseo de infinito son comunes, no son ya estructuras mentales a las que se está obligado a someterse. En adelante, si bien la búsqueda de las grandes dimensiones ciertamente continúa bajo el empuje de las ciencias y de la tecnología, pospone el propósito único de sorprender a la percepción visual en extensión. Y la cultura proyectual de la perspectiva física, espacial y horizontal, se amplía entonces hacia la conquista de la altura, lo cual viene a coincidir con las emancipaciones de las colonias de los grandes imperios. La posibilidad de construir el infinito y de instalar con ello la huella humana en extensión y altura comienza a ser posible.

Debemos enfatizar que el cambio producido en los siglos XVII y XVIII la conquista conceptual y perceptual de la extensión y del infinito fue un proceso europeo; en América y en Asia sucedía por la misma época algo diferente. Y es legítimo suponer que las manifestaciones que se destacan en Europa occidental como intentos de 'conquista del infinito', se habrían dado no sólo por el descubrimiento de la herramienta perspectiva y por la conceptualización teórica del espacio y del infinito por entonces con Kant y Leibnitz , sino que ello fue posibilitado en gran medida porque en la mayoría de su territorio sí puede extenderse la mirada hasta el 'infinito' lo que facilita abarcar los límites del espacio dentro de un horizonte visible, alcanzable y concebible (hasta 4,7 km por la curvatura de la Tierra). Sus espacios en general pueden estimarse planos, con "accidentes geográficos de montaña, pero que son de no más de 400 a 600 m de altitud", como reconoce Benévolo, lo que resulta nimio a quienes estamos acostumbrados a las inmensas alturas de América. Cuando añade que con la perspectiva "arquitectura y naturaleza se ensamblan por fin a la misma escala: [porque] la arquitectura recupera la capacidad de abarcar y dominar el cuadro geográfico extenso, olvidado después del Neolítico", ignora a esa otra arquitectura de muchos lugares, la que, encerrada en valles amplísimos o enfrentada a inmensas cumbres, no puede pretender alcanzar una 'misma escala' con la Naturaleza, ni dominar el horizonte; y, tal vez, ni siquiera pueda concebir la fuga infinita desde un punto de vista, que se postula estático bajo un concepto de espacio-tiempo también estático. Porque al menos en América, los espacios son inabarcables, en extensión y en altura; por eso se les mitifica, y en sus culturas ancestrales la noción cosmogónica prevalente no es estático-espacial sino temporal, formada por ciclos. Y aún antes de la Conquista, en América Latina la concepción de la ciudad como reflejo de mundo no era un sistema expansivo y radial hasta el infinito como los ideales europeos de ese momento, sino que estaba atenida a la medida de la geografía, más que a la imposición del damero, (Figs. 12 y 13). 


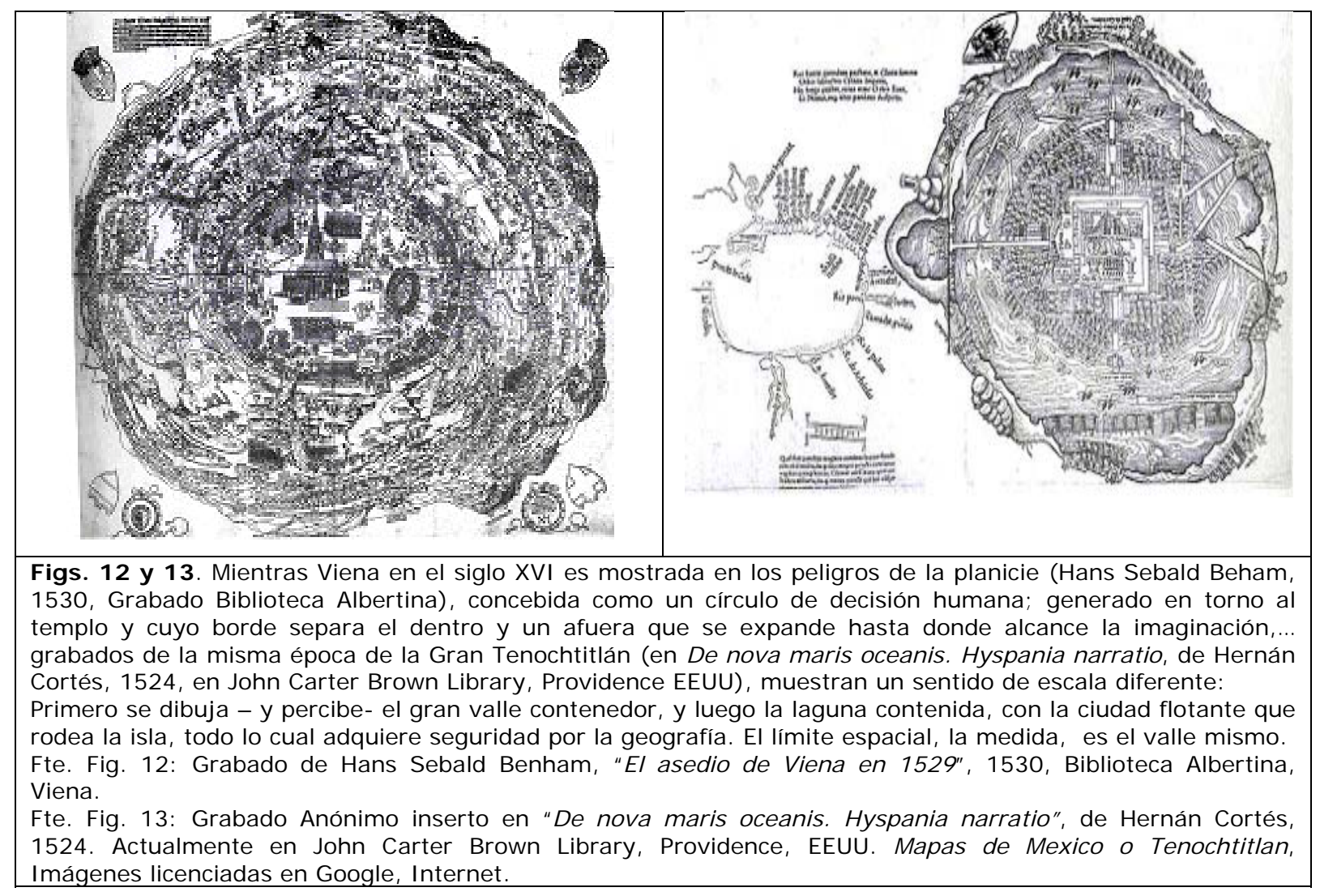

El proceso de conceptualización evolutiva de la escala urbana hasta hoy en la cultura global de la disciplina tuvo su eclosión en los paisajes llanos de Francia y una resistencia en las penínsulas del Mediterráneo: porque, como se dijo, si bien los conjuntos urbanos occidentales grecoromanos por ejemplo Roma o Villa Adriana, eran ya extensos, sus espacios arquitectónicos singulares eran totalidades clausuradas que visualmente no se conectaban entre sí ni buscaban el infinito; esas ciudades no buscaban la certeza de 'una' escala total, como tampoco lo habían hecho los anteriores 'dameros' griegos, aditivos pero no expansivos: en ambos, la 'escala' de conjunto vista hoy se alcanzó por agregación y no como proposición. Y desde nuestra hipótesis, que apuesta al efecto geográfico en la escala, aún si hubiesen sido producidas en el siglo XVII, esos asentamientos no habrían buscado las fugas de perspectiva que buscaron en Francia ciudades como Versalles o Ville Richelieu, porque se sitúan en terrenos visualmente articulados y angostos, como los de Grecia e Italia. Entonces, que Roma no haya adoptado el extensivo urbanismo barroco sino en retazos y en muy escasa medida, no es accidental, (Figs. 14 y 15). 


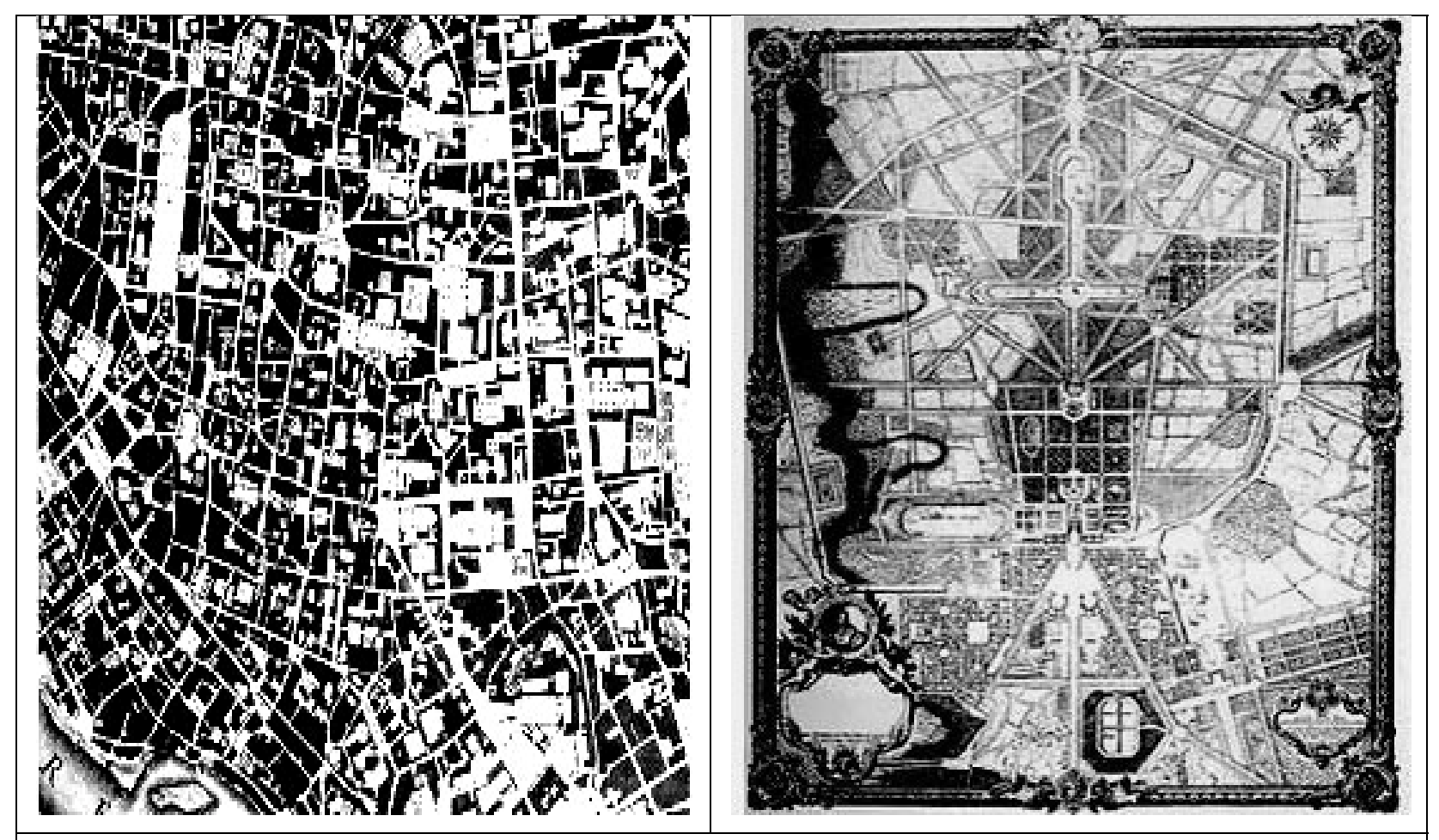

Figs. 14 y 15. En el siglo XVII, la 'escala de Roma' no es concebible en el total sino por las parcialidades de cada punto, piazza o cortile, o lomaje en que se está. Son 'continentes autónomos' cada uno con un vacío pregnante, calzados tal como se habían aglomerado en el período del Imperio, dejando lo exterior como un resto. Por la misma época Versalles - como puede verse en el Proyecto de Le Peutre- y otras ciudades nuevas planificadas en tiempos de Luis XIV, muestran la consciencia del espacio que se extiende más allá. El patio interior ya no importa sino el exterior como sustancia dominable.

Fte. Fig. 14: Ilustra libro de Collin Rowe, Ciudad Collage, Ed. Gili, Barcelona, 1981.

Fte. Fig. 15. Ilustra libro de Philippe Boudon, Richelieu, Ville Nouvelle; Ed. Dunod, Col. Aspect d'Urbanisme, Paris, 1978.

Parece evidente entonces que para el desarrollo histórico de este particular contenido que es la escala, no ha bastado a la disciplina solamente estar en posesión de nociones y de conceptos auxiliares como el infinito o disponer de herramientas como la perspectiva, para la modelación física del paisaje. Porque, aunque ellos eran de común conocimiento y dominio en toda Europa durante el Barroco, su empleo con fines escalares es distinto: sucede que no 'somos' pensamiento como piensa Benévolo - iy antes Descartes!-; más bien parece que nuestro pensamiento es uno con el paisaje. Ello se prueba si revisamos desde nuestra hipótesis territorial el desarrollo conceptual de los dos recursos claves, según el propio Benévolo, para entender el dominio de la escala:

Los ejes, por ejemplo, el recurso base de la perspectiva barroca en Occidente en el siglo XVIII ejes rectos para la organización de elementos que dramatizaran profundidad, y ejes en direcciones diagonales para lograr el dominio total en el plano, aunque eran conocidos y utilizados en otras culturas por la misma época, no siguieron iguales propósitos ni respondían a patrones meramente culturales. Mientras en Europa que puede entenderse mayoritariamente 'plana' sus extensiones son susceptibles de ser conocidas e imaginado su posible dominio, en los territorios inmensos de la China, su propia inmensidad parece revertirse contra el deseo de dominarla, aún si se ostenta el máximo poder político: la Ciudad Prohibida de Pekin nos muestra que el eje más largo del conjunto sólo organiza una sucesión de espacios cerrados y a veces 
autoinclusivos; allí, la consciencia de planicie y de bastedad debe ser de tal grado y tan omnipresente, que se busca pormenorizarla, limitarla o rechazarla, interfiriendo siempre las posibles fugas visuales (Figs. 16 a, 16 b). Por su parte, en el conocido Conjunto Chahar Bagh de Isfahan (1559-1627) actual I rán e igualmente coetáneo del desarrollo perspectivo en Occidente el eje que ordena las parcelaciones de patios con un eje rectilíneo, si bien explícito, tiene no más de $200 \mathrm{~m}$; y, a diferencia de los ejes europeos que intentaban la disolución perceptiva de su término, éste es más un eje de paseo que uno para el dominio visual, ya que sus jardines aledaños son cerrados y deben descubrirse uno a uno. (Fig. 17). En ambos casos no hay idea de perspectiva, y la escala es siempre una impresión parcial; ella no es nunca un recurso para lograr un todo integrador con el paisaje, como se venía consolidado el concepto en occidente.

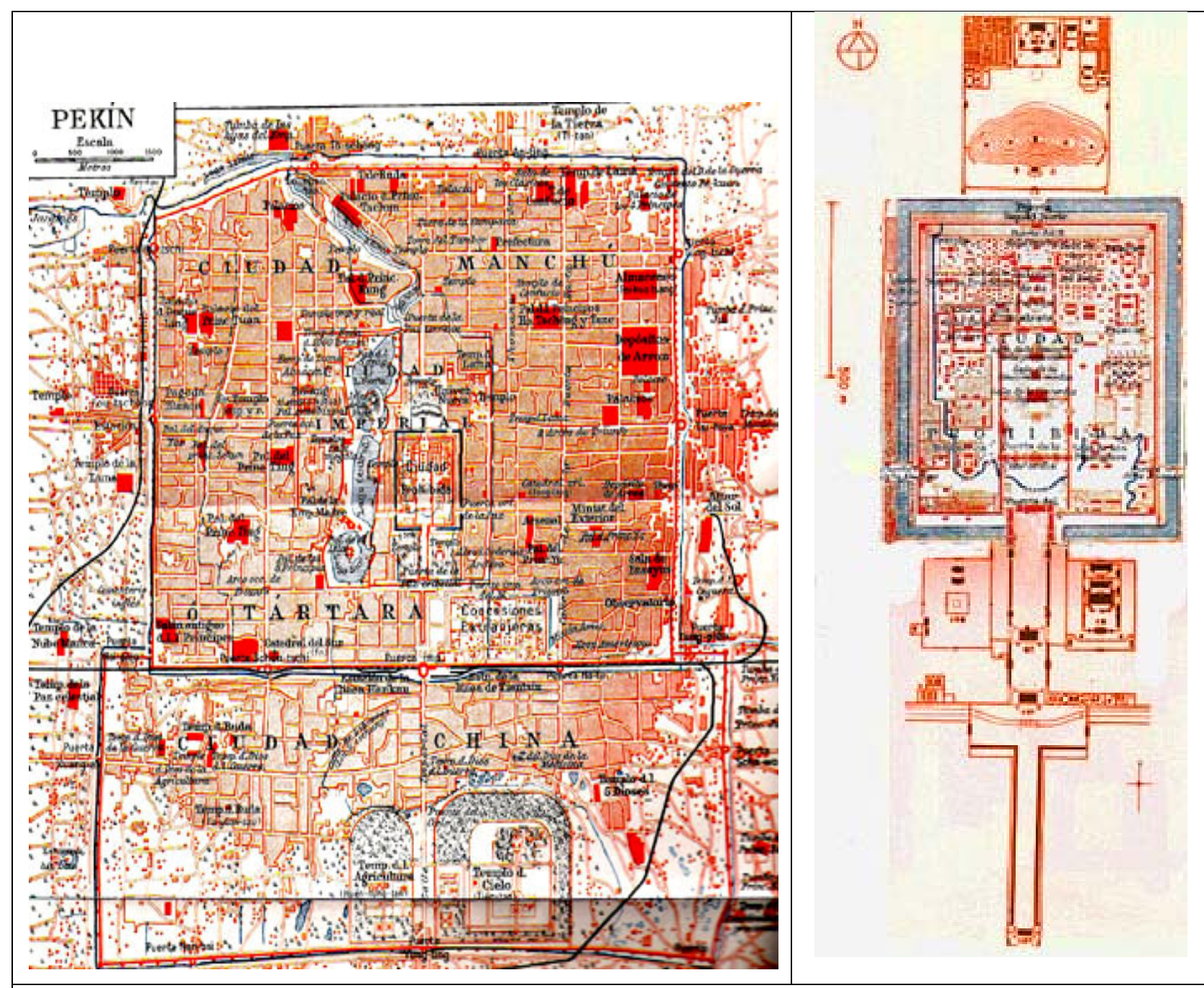

Fig.16 a. La "Ciudad Imperial" conteniendo la "Ciudad Prohibida" (al centro), en el marco de la ciudad de Pekin (ciudad "Manchú o Tártara" y "Ciudad China"). Fte.: ESPASA CALPE S.A., Enciclopedia Universal Ilustrada Europeo Americana, Tomo 42, p., Madrid - Barcelona, 1920, lámina entre pp. 1424-1425.

Fig. 16 b. Detalle de la Ciudad Prohibida, con el eje ceremonial Norte-Sur, sucesivamente interrumpido. (En el extremo sur, en lugar del pasillo de entrada se abre ahora la plaza de Tiananmen).

Fte.: A partir de BENÉVOLO, Leonardo, La captura del infinito, Ed. Celeste, Madrid, 1994, y de: ESPASA CALPE S.A., Enciclopedia Universal Ilustrada Europeo Americana, Tomo 42, p., Madrid - Barcelona, 1920, lámina entre pp. 1424-1425. 


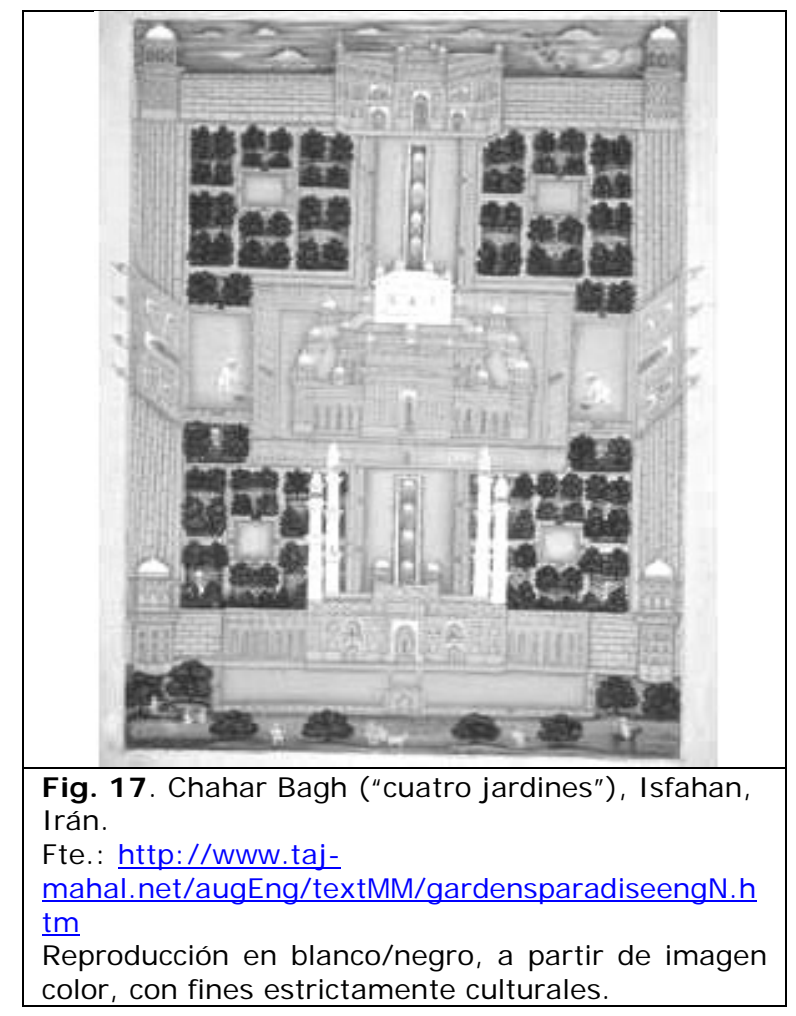

\section{2.- Otras Aproximaciones al concepto de escala.}

La evolución del pensamiento occidental descrita, que sentó las bases occidentales del concepto de escala arquitectónico/urbana, alcanzando un término propio en la disciplina a partir del siglo XIX, no es puramente intelectual. Tiene, a no dudar, raíces profundas en mecanismos perceptuales y de apropiación del espacio social considerado propio, nacidos de la observación cotidiana y empleados inconscientemente, antes de desembocar en un particular deseo de dominio de la escala del todo por medios físicos. A esta aproximación más existencial del concepto, que atribuye la noción misma y la articulación de las progresivas escalas a la visualidad de la arquitectura como hecho sensual de donde se extrae sus invariantes más abstractos como la propia escala , adhiere la línea teórica desarrollada en Chile y España por el arquitecto chileno Juan Borchers y sus seguidores, a partir de finales de la década de los '60 del siglo XX recién pasado, especialmente en la Universidad Politécnica de Madrid. Entre ellos Juan Ramazziotti, por ejemplo, intenta comprobar las condiciones perceptuales para significados como 'próximo', 'cercano' y 'lejano', concluyendo que no es la visión sino la posibilidad táctil - o la imposibilidad-, real o alusiva, la que nos dicta tales significaciones. Desde su enfoque, la escala arquitectónica se articula existencialmente a partir desde 'lo próximo', donde se desarrolla un mundo háptico pleno de relieves aunque en planos escorzados y siempre incompletos; luego establecemos un ámbito de 'lo cercano' que aún 'sentimos como real' y donde las formas se completan y se significa el espacio social; y por último, un ámbito 'lejano' que para la arquitectura no sería infinito, con un radio máximo de $200 \mathrm{~m}$, donde se aplana la sensualidad 'táctil' de los objetos arquitectónicos ${ }^{15}$. Mirado el problema del escalamiento práctico desde el punto de vista existencial y borchersiano que desarrolla Ramazziotti, se explica la longitud sensible de sólo $200 \mathrm{~m}$ que alcanza el citado eje de Isfahan, el cual respondería a una escala de la sensualidad musulmana más que a un intento de dominio del espacio. En el otro extremo de esta misma aproximación existencial, Jesús Bermejo Goday siguiendo más estrictamente la "Metarquitectura" de Borchers sostiene que siendo la arquitectura un artificio que modula el espacio, "mientras más abstracta, es más permanente" (misma premisa que, llevó a Peter Eisenman a desear liberarse del funcionalismo, autonomizando al objeto en tanto puro texto 
$(1984)^{16}$. Bermejo busca invariantes en el tratamiento del espacio, las que supone converger hacia modos universales de percepción; y que la posible autonomía del objeto arquitectónico - para significarlo como 'arquitectura' antes que desde determinada temática- tiene bases precisas en las mecánicas perceptivas. Y entre las invariantes, sitúa las distinciones del sucesivo escalamiento próximo, cercano, lejano- por significación ${ }^{17}$.

En la vanguardia del último tiempo, la escala no sólo ha alcanzado primacía en las decisiones urbano/arquitectónicas, sino que ha llegado a tal grado de independencia lúdica factor en sí de decisiones, no condicionado a restricciones superadas por la tecnología que, por ello mismo, se discute incluso su existencia. Pero este tránsito del modo de operar la escala en el tiempo no ha sido a saltos ni arbitrario. Aunque no constituye un 'perfeccionamiento' de la capacidad perceptual, la que ya contaba como se sabe con toda su agudeza en la antigüedad, muestra sin duda una ampliación incremental de consciencia espacial en la disciplina junto con una articulación irreversible del pensamiento, que permanecen vigentes con sólido fundamento.

\section{3. - I deas y producción de Escala Urbana.}

Sea como resultante involuntario o propositivo, es evidente que tanto la producción de escala como su lectura apreciativa pueden estudiarse también legítimamente como producción simbólica, al contrastarla con la cosmovisión o el discurso imperante acerca del asentamiento humano, en un sentido filosófico. Aunque tales planos permanecen generalmente en estado subconsciente, tal dimensión de la escala interesa a artistas, diseñadores y arquitectos más que a otros; y su búsqueda de las relaciones entre lo objetivo y lo subjetivo no debe extrañar, por cuanto según Néstor García Canclini, ellos experimentan materialmente la indiscutible vinculación entre su hacer y su mundo simbólico ${ }^{18}$. Este vínculo entre lo objetivo y lo subjetivo, entendido éste último 'permeado' por elaboraciones ideológico culturales donde se diluye lo personal en lo social, es lo que lleva a Collin Rowe (1981) a estudiar, por ejemplo, la evolución de las ciudades como 'expresión material de utopías sociales o políticas', dejando patente que la escala es un indicador elocuente de tales deseos (a pesar de que no es el propósito del texto y escasamente menciona la escala $)^{19}$. Y en el mismo sentido pero desde la fuente de arquitecturas imaginarias, dibujadas o pintadas , transcurre la pesquisa que realiza el español J osé Antonio Ramírez (1988): aborda los relatos presentes en las utopías, revisando aspectos narrativos y descriptivos que nos muestran que los rasgos espaciales dejando traslucir que también la escala dependen del ideal imperante. Postula que si la arquitectura expresa la mirada de un momento, en mayor y mejor medida lo hacen la pintura o dibujos sobre arquitectura, dada su mayor libertad física. Las pinturas, especialmente, contienen y condensan la mirada que se tiene sobre la propia potencia y capacidad social del grupo, en un momento dado ${ }^{20}$.

De las abundantes ilustraciones que Ramírez analiza desde el Renacimiento hasta los años'60 del siglo pasado , podemos deducir fácilmente, entre otros, los enunciados de relatos que informaron los deseos escalares del pasado próximo y que incidieron en las utopías racionalistas, expresionistas o metabolistas; relatos que de alguna manera modelan aún el concepto occidental de escala. Los relatos deducibles de las ilustraciones, (Figs. 18 y 19) a partir de los ideales 'motores' de la 'escala ideal de los '60' resumidamente , serían:

- Previsiones demográficas alarmantes (compactación de habitáculos, organizados en alturas inmensas).

- Liberar el suelo (ecologismo, naturalismo, consciencia de escasez de suelo).

- 'Propósito de un espacio común y público más digno' (para la sociedad en colectivo).

- Integrarse al cosmos (altura inmensa, tecnología 'de punta', formas aérodinámicas).

- Protección de catástrofes y vandalismo (arquitectura subterránea, o alejada del suelo.

- "Vida urbana libre y democrática" (edificios idénticos, libertad a las masas en grandes espacios públicos). 
- Futuro inestable, relaciones efímeras (arquitectura cambiante, modificable; casual).

- Ahorro de energías (Tipificación, concentración, tecnologías alternativas).

- Facilitar el cambio (arquitectura prefabricada, cambiante, modificable).

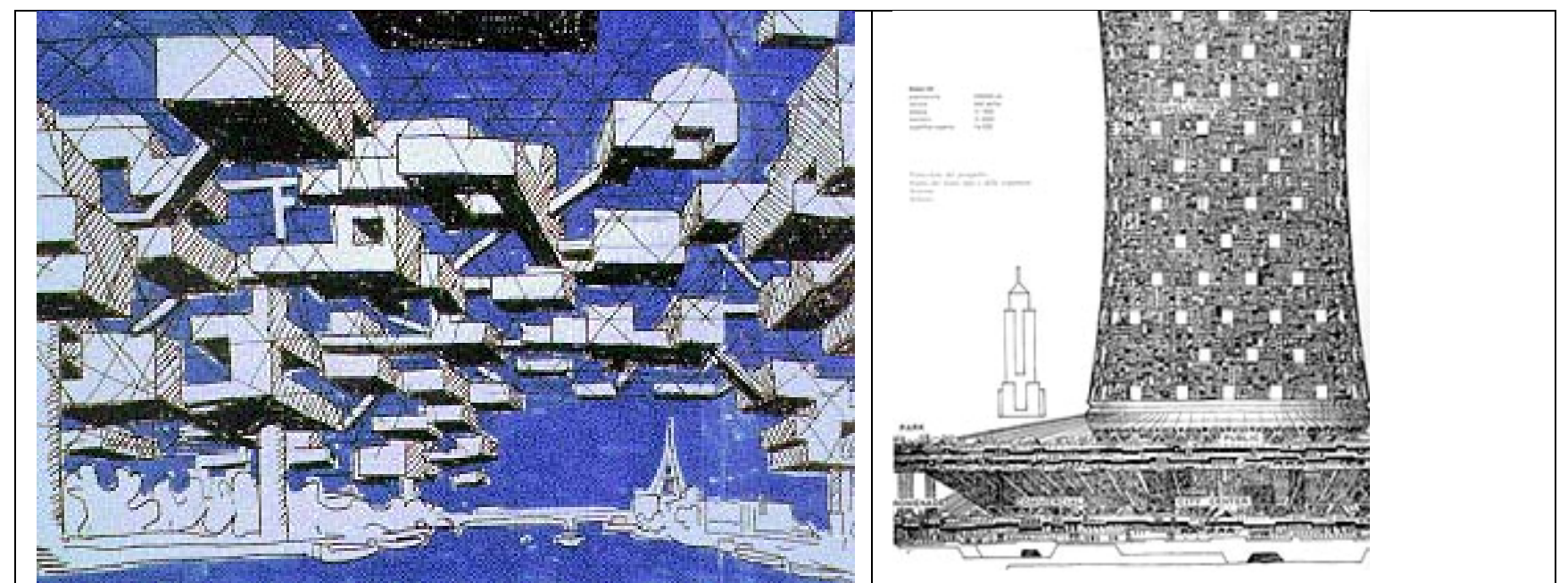

Figs. 18 y 19. Escala urbana del deseo en espacios sin 'escala vertical' del territorio natural: 'París paralelo' de Yona Friedman, y Megaestructuara de Paolo Soleri ideada para la planicie americana.

Fte. Fig. 17: Imagen dibujo original de Yona Friedman, «Paris paralelo », en Imágenes licenciadas en Google, Internet.

Fte. Fig. 18: Megaestructura de Paolo Soleri, "Comparación con Empire Satate Building". En Imágenes licenciadas en Google, Internet.

Entendiendo por 'ideas' aquellas nociones organizadas y elaboradas que llevan a creaciones en lo que nuestro Modelo es coincidente con lo que J. Seguí describe como "Ios proyectos (de acción), las decisiones activas, las convicciones. No las 'preexistencias' (arquetipos platónicos) sino las determinaciones"21... , resulta evidente que los relatos motores que derivamos de los ejemplos de J. A. Ramírez son ideas/proyecto de este tipo, las que en sí implican 'una' escala. Elaboraciones complejas que se sintetizan en un propósito; que, si bien apuntan a varios planos de realidad, si nos fijamos bien, todas ellas contienen un germen de otra idea en un plano paralelo en el plano de los órdenes de magnitud : paralelo a la idea de la capacidad humana en el presente, aparece la idea subsidiaria que induce y converge en cada caso al resultado posible de determinada escala urbana y arquitectónica, en instancia de creación o de lectura.

Entonces, si la lectura de la escala de una urbe es resultado no sólo de relaciones de tamaños sino también del concepto del territorio y del reconocimiento de formas como dice S. González , pero éstas a su vez son resultado de ideas que portan su propio germen de magnitud ${ }^{22}$, la atención puesta sobre las formas que surgen de las utopías recientes es también una mirada muy válida a las claves de la escala urbana y la edilicia contemporánea.

Y otros conceptos o ideas subyacentes, que parecerían a algunos tan indiscutibles y objetivos como 'Ia escala humana', son en realidad conceptos ideológicos, bastante variables y que no siempre han existido; al menos no de la misma manera, aunque algunos postulen la inmanencia de una 'escala humana eterna' como algo natural en las obras de los hombres. Sin embargo, para muchos representa una referencia ergonómica y ergonométrica de correspondencia dimensional con el cuerpo mientras para otros, más que dimensiones, implica la preocupación por lo humano individual y social en un sentido amplio, y trasunta sus alcances integrales. El renombrado arquitecto español Alejandro Zaera Polo, observaba recientemente que la existencia de una 'escala humana natural' y eterna sólo puede defenderse aún desde las posiciones más conservadoras, 
..sostenidas como verdaderas cruzadas éticas que intentan evitar una supuesta pérdida de control, de dominio y de orden en las ciudades. Pero, a pesar de su voluntarismo aparente, ese reclamo escalar que es adjudicar 'escala humana', le parece una necesidad de la arquitectura, aunque en un sentido distinto: "Humanismo y materialismo son categorías más bien opuestas, pero que necesitamos que se retroalimenten en la arquitectura, que es en último término organización de materia"23.

De lo anterior nos permitimos deducir que el fenómeno escala no sólo responde o refleja ideas concurrentes en un mismo sentido, sino que además puede conciliar opuestos. En consecuencia, no bastaría para la comprensión de la escala entender sólo las ideas que la inspiran reflejadas allí, al modo platónico en que lo entiende F. Irigoyen ${ }^{24}$ y las concibe C. Norberg Schulz en Genius Loci, ${ }^{25}$ por ejemplo, para quien las ideas son verdaderos 'arquetipos' modelados por la relación con el lugar que comandan niveles ideológicos de apropiación; cosa que según sostiene, se reconocería en la oposición romántico/clásico, u otras oposiciones que se producen en lo local. No basta, porque la idea en la escala, como se vio, es un marco de propósito significativo más complejo que contiene, de suyo y cada una, un germen dimensional, incluso cuando ellas se actúan como arquetipos.

Sea que la escala responda a modos de dominio perceptual, de significación y de conocimiento de la realidad, o bien que resulte como expresión simbólica y represente utopías independientes de la realidad lo subjetivo, lo que está claro es que en cualquier caso ella se opera finalmente desde ideas; y éstas, no sólo como patrones a calzar reactiva y deductivamente con lo que se enfrenta sino también como verdaderos 'motores de búsqueda' de 'lo adecuado' en la metáfora de Ph. Boudon $^{26}$; búsqueda inductiva pero también abductiva y retroductiva agregamos , a completarse en forma creativa a partir de la propia sustancia de las obras y de los estímulos espaciados en la ciudad. Porque en último término, la mente transforma el estímulo de la sustancia dimensionada para producir 'escala' creativamente, cada vez, un atributo nuevo instanciado en la circunstancia.

Y si bien, desde el punto de vista existencial, la escala se hace 'casi' equivalente o coincidente con el concepto de espacio al ser tan abstracta como éste, en la práctica ella depende de tal modo de la materia, de la sustancia física y de su disposición y dimensiones, que podría estudiarse eficientemente desde la pragmática. Pero la realidad se nos entrega 'escalada', no siempre en forma explícita sino más bien encriptada en códigos que hemos construido con andamios de psiquismo significante para entender el mundo físico; lo cual nos obliga a reparar, no tan sólo en los códigos escalares mismos, sino en los contenidos que llevan a las sociedades a esas reglas y operaciones heurísticas, identificando las claves físicas de los lugares que desencadenan esta actividad profunda intencional y creativa que es el 'escalaje' que se tiene por adecuado o deseado en determinado momento. 


\section{Referencias:}

1. GUATTARI, Felix. "Ritournelles et effects existentielles". En Rev. Chimères № 7, Paris, 1989.

2. LETELIER, Sofía. Lectura e Ideación de la Escala Arquitectónica. Tesis Doctoral, U. Politécnica de Madrid, 2007.

3. FOSCARI, Mario. “The Building of Architecture”. En Rev. Vía № 7, 1984.

4. MALPAS, J eff. "Place and Topography". En Rev. Environmental and Architectural Phenomenology, Newsletter, 2004.

5. SEGUí, Javier. Formar. (Carta a Conchita), Documento inédito con forma epistolar. 20/8/2004.

6. RAPPOPORT, Nina. "Architectural League's Annual Competition 1999". En Rev. Young Architects, № especial Scale, 2000.

7. RAMONEDA, Joseph (prologista). Las Casas del Alma; catálogo. Ed. Fundación Caja de Arquitectos, Barcelona, 1997.

8. AZARA, Pedro, "La Imagen de la Arquitectura en el Mundo Antiguo". En Las Casas del Alma, Catálogo Exposición Las Casas del Alma, Ed. Fundación Caja de Arquitectos, Barcelona, 1997. P: 11.

9. WORRINGER, Wilhem, La esencia del Estilo Gótico, Ed. Nueva Visión, Bs. As.1967.

10. VIOLLET- LE DUC, Eugène. Diccionario de Arquitectura. En, Boudon, Ph. 'Del espacio Arquitectónico', Ed. Victor Lerú, Bs. As, 1980.

11. PANOFSKY, Edwin. "Arquitectura Gótica y Escolástica". Ed. De la Piquera, Madrid, 1986

12. VAN ECK, Caroline. "Architecture, Lenguage and Rethoric in Alberti's De Re Aedificatoria", (capítulo). En Architecture and Language. Constructing Identity in European Architecture. c. 1000-1650. Klark, G / Crossley, P. (editores), Cambridge Univ. Press, London, 2000.

13. BENÉVOLO, Leonardo. . “La captura del infinito”, Ed. Celeste, Madrid, 1994. P.: 83.

Nota: Se refiere al hecho de comenzar por entonces a considerarse en forma generalizada precisamente la dependencia entre espacio y cuerpos que anticipaba Alberti; hecho con que se consolida la progresiva sustitución del juego interno y ensimismado de la proporción clásica, por otro que conscientemente amplía las relaciones hacia el resto; ensayo que se prolongará durante los siglos XVI y XVII, aunque sólo todavía en el plano de extensión horizontal y posteriormente hacia la vertical en el siglo XVIII.

14. Nota: Lo que Benévolo llama 'perspectiva', no es la herramienta gráfica representacional, si no la impresión de fuga física.

15. RAMAZZIOTTI, Juan. Huellas Espaciales de la dimensión humana. Tesis Doctoral, ETSAM, UPM, Madrid, 1998.

16. EISENMAN, Peter. "The End of Classical”, en Rev. 'Perspecta', The Yale Architectural J ournal № 21, 1984.

17. BERMEJO GODOY, Jesús. El espacio Arquitectónico como extensión heterogénea. Una contribución a la obra de J. Borchers. Vol. 1 y 2. Tesis UPM, Madrid, 1978.

18. GARCÍA CANCLINI, Nestor. La producción simbólica. Teoría y método de la sicología del arte. Ed. Siglo XXI, México, 1998. P.: 83.

19. ROWE, Collin. Ciudad Collage, Ed. Gustavo Gili, Barcelona, 1981, P.: 50-54.

20. RAMíREZ, José Antonio. Construcciones Ilusorias, Alianza Forma, Madrid, 1988. Capítulo final.

21. SEGUí, Javier. “El Pensamiento Gráfico”. Ponencia en Congreso EGA, Granada, 05/04/2004. Documento $s / p$.

22. GONZÁLEZ, Sergio. “La Escala”. Cuadernos de Arquitectura № 10, Ed. ESCALA, Bogotá, enero, 1985.

23. ZAERA Polo, Alejandro. "Mind after Matter". Capítulo en Matter and Mind in Architecture, editor Pirkko Tuukkanen, Alvar Aalto Foundation, Helsinki, 2000. P: 101 
24. IRIGOYEN, Francisco. Filosofía y Diseño. Una aproximación epistemológica. UNAM, México, 1998. P: 30-38.

25. NORBERG Schulz, Christian. Genius Loci. .Towards a Phenomenology of Architecture, Academy Editions, London, 1980.

26. BOUDON, Philippe. El Espacio Arquitectónico, Ed. Víctor Lerú, Bs. As. 1980. 